\title{
Czy do ważnego zawarcia sakramentalnego małżeństwa potrzebna jest wiara?
}

\section{Niejednoznaczność współczesnego pojmowania wiary}

Ażeby podjąć ten problem, trzeba przede wszystkim rzetelnie wyjaśnić, jakiej wiary nasze pytanie dotyczy. Wydaje się, że byłoby czymś zbyt ogólnikowym powiedzieć, że chodzi nam o wiarę katolicką albo może nawet tylko o jakieś pozytywne otwarcie na to, w co wierzy Kościół.

Mentalność współczesna wiarę religijną rozumie alternatywnie (a może nawet komplementarnie - to dla naszego wywodu nie wydaje się istotne) jako:

1. przekonanie o prawdziwości tego, co głosi Ewangelia i naucza Kościół, krótko mówiąc, jako wyznawanie chrześcijańskiego światopoglądu;

2. albo też jako otwarcie się na osobowe relacje z Bogiem i Chrystusem, jako zawierzanie siebie i swoich spraw Bogu, który nam się objawił w Jezusie Chrystusie.

Otóż wiary w obu przedstawionych tu rozumieniach może doświadczać również człowiek nieochrzczony. A mimo to brak chrztu stanowi przeszkodę zrywającą również dla katechumena, choćby był on już człowiekiem głęboko wierzącym. Rozdział dotyczący obrzędów zawarcia małżeństwa z osobą nieochrzczoną, jaki 
znajduje się w obowiązującym w naszym polskim Kościele rytuale sakramentu małżeństwa, zaczyna się od wyjaśnienia, że „chodzi tu zarówno o katechumenów, jak i o niechrześcijan”.

Św. Tomasz z Akwinu nie ma wątpliwości, że również w sytuacji, kiedy wszystkie warunki zawarcia ważnego małżeństwa wydają się dopełnione, narzeczony zaś, mimo że jeszcze nieochrzczony, jest człowiekiem jednoznacznie i po katolicku wierzącym, jego ślub z osobą ochrzczoną byłby nieważny: „Gdyby katechumen mający prawdziwą wiarę, ale jeszcze nieochrzczony, poślubił jakąś wierną, która jest ochrzczona, nie byłoby to prawdziwe małżeństwo"2.

Już katechumeni - jak przypomniał ostatni sobór w dekrecie Ad gentes, 14 - „nierzadko prowadzą życie wiary, nadziei, miłości”. (Zauważmy, że zarówno w pierwszym, jak i w najnowszym polskim przekładzie tekstów soborowych osłabiono sens tej wypowiedzi i frazę „vitam agunt fidei, spei et caritatis” oddano jako: „prowadzą życie nacechowane wiarą, nadzieją i miłością”). Z równą otwartością wobec katechumenów kanon 206 KPK orzeka, że pragnienie oraz praktykowanie wiary, nadziei i miłości łączy ich z Kościołem, „który już teraz wspiera ich jako swoich”. Pozytywny stosunek do katechumenów oraz do ich wiary znajdziemy też w Katechizmie Kościoła Katolickiego, 1249.

Postawmy proste pytanie: Dlaczego nawet ta wiara katechumena, o której z taką aprobatą wspominają wymienione przed chwilą bardzo ważne dokumenty Magisterium, nie usuwa przeszkody zrywającej w postaci disparitas cultus? Postawmy to samo pytanie

1 Obrzędy sakramentu małżeństwa dostosowane do zwyczajów diecezji polskich, wyd. 2, Katowice 1986, s. 39.

2 "Si aliquis catechumenus, habens rectam fidem sed nondum baptizatus, cum aliqua fideli baptizata contraheret, non esset verum matrimonium" (4 Sent., dist. 39 a. 1 ad $5=$ sTh Suppl. q. 59 a. 1 ad 5). Zwróćmy uwagę, że polski tłumacz tego zdania termin aliqua fidelis oddaje błędnie jako osoba wierząca. Różnicę między fides i credere spróbujemy za chwilę wyjaśnić. 
od innej strony: O jaką wiarę prosi Kościół Boży przystępujący do chrztu i zasadniczo już wierzący katechumen, kiedy na pytanie chrzciciela: „O co prosisz Kościół Boży?”, odpowiada: „O wiarę”3. Doprowadźmy nasze pytania do końca: Czyżby Kościół potrafił obdarzyć wiarą nawet niemowlę, któremu żadne pouczenie wiary nie mogło być jeszcze udzielone, skoro podczas jego chrztu rodzice i chrzestni odpowiadają podobnie: że proszą dla swojego dziecka o wiarę?

\section{Co to jest wiara?}

Biblijną jakby-definicję wiary, o której odzyskanie spod zniekształcających ją nowożytnych przekładów Biblii upomniał się ostatnio Benedykt XVI w encyklice Spe salvi, przedstawię za chwilę. Teraz punktem wyjściowym naszej odpowiedzi na pytanie, co to jest wiara, niech będzie potoczne przekonanie wiernych, dla których - jak się wydaje - wiara jest to realna zdolność do kontaktów z Bogiem i Chrystusem. Wyłaniane przez nas akty wiary tę zdolność potwierdzają, bo przecież dzięki niej w ogóle mogą zaistnieć. Co więcej, akty te wiarę w nas utrwalają i pogłębiają.

Wiara jednak nie utożsamia się ze swoimi aktami, jest ona w człowieku czymś głębszym i wcześniejszym niż podejmowane przez nią akty - podobnie jak rozum jest w nas czymś głębszym i wcześniejszym niż akty rozumu (np. niewątpliwie jest on już w niemowlęciu, mimo że nie jest jeszcze ono zdolne do aktów rozumu).

3 Obrzędy chrześcijańskiego wtajemniczenia dorosłych, Katowice 1988, s. 43.

4 Por. KKK 1253. Wprawdzie u nas w Polsce w liturgii chrztu niemowląt dominuje odpowiedź bardziej zgodna z współczesną nominalistyczną mentalnością, jednak odpowiedź „O wiarę” jest również dopuszczona (Obrzędy chrztu dzieci wedtug Rytuału Rzymskiego, Katowice 1972 s. 34). O wiele mocniej tę właśnie odpowiedź podkreśla papież Benedykt XVI w encyklice Spe salvi, 10. 
W ostatnich latach wiara była w całym Kościele katolickim przedmiotem intensywnego namysłu, a to w związku z ogłoszonym przez Benedykta XVI listem apostolskim Porta fidei, który ustanawiał rok 2013 Rokiem Wiary. Mam rację albo jej nie mam, bo badań na ten temat nie prowadziłem, wydaje mi się jednak, że w wykładach, odczytach, kazaniach, jakie wówczas w związku z Rokiem Wiary głoszono, prawie nie mówiono o samej wierze. Koncentrowano się niemal wyłącznie na aktach wiary, poprzez które - oczywiście - wiara się przejawia, rośnie, ale które z wiarą się jednak nie utożsamiają.

Otóż wydaje się, że kwestionowanie z powodu braku wiary ważności małżeństwa zawartego przez ochrzczonych nupturientów wywodzi się z tego spłaszczonego pojmowania wiary, gdzie wiara utożsamiana jest z jej aktami. Toteż w największym skrócie przypomnijmy, czym są akty wiary oraz czym jest sama wiara.

Tomasz z Akwinu rozróżnia trzy rodzaje aktów wiary: „wierzę, że”, następnie „wierzę Bogu” i wreszcie „wierzęw Boga”'. „Wierzę, że” dotyczy materii wiary - tym aktem uznajemy prawdziwość tego, co stanowi przedmiot wiary. W Wykładzie Listu do Rzymian Akwinata zwraca uwagę na to, iż nie zawsze „wierzę, że” jest aktem wiary nadprzyrodzonej. Na akt taki może się bowiem zdobyć również człowiek, w którym takiej wiary nie ma - mianowicie jeżeli do danej prawdy doszedł na przykład „dzięki jakimś ludzkim argumentom i naturalnym znakom” ${ }^{6}$. W tym spostrzeżeniu Doktora Anielskiego szukałbym wyjaśnienia, dlaczego Kościół lęka się dopuszczać do ślubu nawet niewątpliwie wierzących katechumenów. Nie ma przecież pewności, że ich wiara jest wiarą nadprzyrodzoną, gdyż mogła się w nich zrodzić z całkiem ludzkich powodów, zapewne pozytywnych, a może nawet chwalebnych.

5 Św. Tomasz z Akwinu, Summa Theologiae, 2-2 q. 2 a.2.

6 Św. Tomasz z Akwinu, Wykład Listu do Rzymian, cap. 4 lect. 1, nr 327. 
Owocem wiary nadprzyrodzonej są natomiast niewątpliwie akty „wierzę Bogu”. Sam Bóg jest inicjatorem naszych z Nim relacji i to Jego łaska uzdalnia nas do tego, żebyśmy Jego wezwania mogli słyszeć i na nie odpowiadać. Możliwe jest to nawet wtedy, kiedy znajdujemy się w grzechu, czyli kiedy utraciliśmy łaskę uświęcającą. Do aktów „wierzę Bogu”, które doprowadzą nas do jej odzyskania, uzdalniają wówczas grzesznika łaski uczynkowe.

Trzecim, najdojrzalszym rodzajem aktów wiary, jest „wierzyć w Boga”. „Wierzyć w Boga - pisze św. Tomasz w cytowanym przed chwilą fragmencie Wykładu Listu do Rzymian - wskazuje na ukierunkowanie wiary do celu, co się dokonuje przez miłość: ponieważ wierzyć w Boga znaczy wierząc iść ku Bogu, a to sprawia miłość”. Do takich aktów zdolni jesteśmy tylko w stanie łaski uświęcającej, bo tylko wtedy o naszej wierze możemy powiedzieć, że jest ona ukształtowana przez miłość (fides caritate formata).

Przedstawiłem trzy rodzaje aktów credere. Zapytajmy teraz, czym jest fides, wiara, z której te akty wypływają. To, że wiara jest czymś innym niż jej akty, tzn. niż jej przejawianie się w naszym życiu i postępowaniu, najprościej można pokazać na przykładzie chrztu niemowlęcia. Niemowlę jest jeszcze niezdolne do aktów wiary, a przecież w sakramencie chrztu łaskę wiary już otrzymuje. Rodzice i środowisko chrześcijańskie pomogą mu w wierze rosnąć i dawać jej świadectwo poprzez różnorodne akty wiary.

Swojego rodzaju definicja wiary znajduje się w Hbr 11, 1: „Wiara jest podstawą tych dóbr, których się spodziewamy, dowodem tych rzeczywistości, których nie widzimy”. Benedykt XVI, przypominając w encyklice Spe salvi ogromne znaczenie tego zdania dla naszego rozumienia wiary, upomina się zarazem o uwolnienie go od dezinterpretacji, którym uległo ono w nowożytnych przekładach Biblii.

Kluczowym terminem w tekście oryginalnym tego wersetu jest wyraz hypostasis. „Dla [zachodnich] Ojców Kościoła i teologów 
Średniowiecza było jasne, że greckie słowo hypostasis należało tłumaczyć na łacinę jako substantia"7 - kalką obu tych terminów, i greckiego i łacińskiego, jest polski wyraz podstawa. Również élenchos (po polsku „dowód”), drugi co do ważności termin wyznaczający sens tego wersetu, ma sens nie subiektywny, ale obiektywny, wskazuje na jakąś obecną w nas rzeczywistość. Tymczasem w Biblii Lutra oba te terminy oddano w sensie subiektywnym. Hypostasis Luter oddał jako eine gewisse Zuversicht (swojego rodzaju ufność, przekonanie), élenchos jako das Nichtzweifeln (niepowątpiewanie). Całe zdanie ma w Biblii Lutra sens mniej więcej następujący: Wiara jest swojego rodzaju przekonaniem o tym, co do czego ma się nadzieję, oraz niepowątpiewaniem o tym, czego się nie widzi (Hbr 11, 1).

W swojej encyklice Benedykt XVI z satysfakcją odnotowuje, że współczesna egzegeza protestancka dystansuje się od luterskiego rozumienia wiary. Papież cytuje wybitnego biblistę protestanckiego Helmuta Köstera: „Obecnie nie można mieć wątpliwości, że ta protestancka interpretacja, która stała się klasyczną, jest nie do utrzymania" ${ }^{\text {. }}$

Zobaczenie w wierze wymiaru obiektywnego, odejście od rozpowszechnionego dzisiaj sprowadzania wiary tylko do przekonań albo tylko do subiektywnej postawy ufności i zawierzenia, umożliwia rozpoznanie wiary jako realnego, a zarazem transcendentnego wobec empirii początku życia wiecznego. Podejmując pytanie o znaczenie wiary dla ważnego zawarcia sakramentalnego małżeństwa, zdecydowanie należy przestudiować wykład na temat wiary, jaki znajduje się w encyklice Spe salvi, zwłaszcza w numerach 7-10.

7 Benedykt XVI, enc. Spe salvi, 7.

8 Spe salvi, 7. 


\subsection{Znaczenie wiary dla ważności i owocności sakramentu małżeństwa}

Wiara jest więc - jak uczy w swojej encyklice Benedykt XVI, przywołując definicję Tomasza z Akwinu - „stałym nastawieniem duszy, dzięki któremu życie wieczne bierze w nas początek, a rozum jest skłonny przystać na to, czego nie widzi”. Zatem okazuje się, że tradycyjne w prawie kanonicznym ujęcie, według którego katolikiem jest osoba, która „została ochrzczona w Kościele katolickim lub została do niego przyjęta"9, nie jest dziełem prawniczej wygody, ale ma głębokie uzasadnienie teologiczne. To dzięki sakramentowi chrztu człowiekowi przysługuje tytuł fidelis, czyli kogoś, kogo Bóg obdarzył łaską wiary.

Tego daru nie traci się nawet przez osobistą niewierność. Jedynie formalnie podjęta apostazja powstrzymuje Kościół od zaliczania ochrzczonego w nim człowieka do grona wiernych. Tradycyjnie, człowieka, który raz został obdarzony wiarą (homo fidelis) i od niej odstąpił, nazywano „wiarołomcą” (perfidus) i nigdy nie ośmielono by się nazywać go człowiekiem bez wiary (infidelis). W tym właśnie kierunku zdają się zmierzać decyzje Benedykta XVI z motu proprio Omnium in mentem. Toteż nawet tych ochrzczonych, którzy dokonali formalnej apostazji, starajmy się nie nazywać ludźmi niewierzącymi.

W czasach nowożytnych pojęcie fidelis ulega niedobrej podmianie. Pojawiło się pojęcie „ludzie wierzący”, czyli ludzie świadomi swojej wiary i starający się jakoś ją praktykować. W rezultacie, niewierzącymi nazywamy również ludzi ochrzczonych, jeśli wiara przestała się w ich życiu praktycznie liczyć. Otóż pojęcie

9 KPK kan. 1086 \& 1. Odnotujmy, że papież Benedykt XVI, w motu proprio Omnium in mentem (26.10.2009), polecił, ażeby w tym kanonie oraz w kanonach 1117 i 1124 powrócić do tej tradycyjnej formuły i zrezygnować z dodatku (,i nie odłączyła się od niego formalnym aktem”), jaki znalazł się w nowym Kodeksie prawa kanonicznego. 
non credentes nie jest synonimem pojęcia infideles ${ }^{10}$. Niewierzący to człowiek, który nie podejmuje aktów wiary. Ale przecież zaniechanie przez człowieka ochrzczonego aktów wiary, a nawet osobista świadomość bycia niewierzącym - chociaż dla złożonego w nim przez chrzest daru wiary jest to sytuacja wysoce niepożądana - daru tego nie usuwa. Świadczą o tym wcale nierzadkie przypadki tego, co potocznie uważa się za odzyskanie wiary, a co faktycznie jest raczej jej ożywieniem po krótszym lub dłuższym okresie jej hibernacji lub nawet obumierania.

To dlatego zarówno prawo kanoniczne, jak zwyczajna gorliwość duszpasterska każe zrobić wszystko, ażeby również ci katolicy, którzy w wierze się pogubili, mogli przystąpić do ślubu jako religijnie odnowieni. Zarazem przystąpienie przed zawarciem małżeństwa do sakramentu pokuty i Najświętszej Eucharystii ani nawet przyjęcie sakramentu bierzmowania - choć usilnie przez Kościół zalecane ${ }^{\mathrm{Il}}-$ zdecydowanie nie jest wymagane do ważności ślubu kościelnego.

Owszem, duszpasterze powinni odradzać zawierania małżeństwa z osobą choćby tylko nieformalnie zdystansowaną wobec wiary i Kościoła. Poprzedni Kodeks mówił o tym bardziej szczegółowo w kanonie 1065: „Wiernym należy utrudniać zawieranie małżeństw z osobami, które jawnie porzuciły wiarę katolicką, chociaż nie zapisały się do żadnej sekty niekatolickiej, jak również z osobami, które zapisały się do stowarzyszeń potępionych przez Kościół. Proboszcz nie powinien asystować przy zawieraniu takich małżeństw bez porozumienia się z ordynariuszem, który

10 Znamienna wydaje się nieobecność terminu non credentes w dokumentach kościelnych. Wprawdzie we wszystkich opublikowanych na stronach Stolicy Apostolskiej przekładach adhortacji Familiaris consortio termin ten znalazł się w jednym z podtytułów: „Obrzęd ślubu i ewangelizacja ochrzczonych niewierzących” (nr 68). Jednak w łacińskim oryginale tego podtytułu nie ma. Por. Acta Apostolicae Sedis 74 (1982) nr 2, s. 163.

11 KPK kan. 1065. 
po rozważeniu wszystkich okoliczności może pozwolić na ślub, jeśli przynagla ważny powód oraz jeśli jego zdaniem istnieją dostateczne rękojmie, że potomstwo zostanie wychowane po katolicku, a wierzącemu współmałżonkowi nie będzie zagrażało żadne niebezpieczeństwo utraty wiary"12.

Zatem nawet jeżeli do opisanych w powyższym kanonie związków Kościół zdecydowanie nupturientów zniechęcał, nie było mowy o tym, jakoby małżeństwo w takich okolicznościach zawarte miało być nieważne.

Wydaje się, że przyjęcie braku wiary - pojmowanej w sensie nowożytnym, niezgodnym z tradycyjnym nauczaniem Kościoła o darze wiary - byłoby aktywnym włączeniem się Kościoła na rzecz swojej własnej depopulacji.

Otóż nie widać powodów, dla których wolno by nam było naruszyć tę równowagę, którą w podejściu do pytania o to, czy w zlaicyzowanym społeczeństwie dopuszczać do ślubu ludzi ochrzczonych, bardzo nawet od wiary oddalonych, zaproponował Jan Paweł II w adhortacji apostolskiej Familiaris consortio, 68. Zawarte tam wskazówki można streścić w czterech następujących punktach:

1. Zadaniem duszpasterzy jest pomagać tym osobom w odkryciu i ożywieniu wiary, ale zarazem starajmy się zrozumieć powody, dla których Kościół dopuszcza do ślubu „także tych, których usposobienie nie jest doskonałe”.

2. Faktem jest, że dzisiaj „na niektórych obszarach raczej względy społeczne niż prawdziwie religijne skłaniają narzeczonych do zawarcia małżeństwa w Kościele”. Święty papież zwraca uwagę na to, że wielu tych ludzi chce - „nawet jeśli w sposób nie całkiem uświadomiony” - małżeństwa zgodnego z Bożym zamysłem. Ponadto, „nie powinno się zapominać, że ci narzeczeni, na mocy chrztu, są już rzeczywiście włączeni w oblubieńcze Przymierze

12 E. Sztafrowski, Chrześcijańskie matżeństwo, Warszawa 1985, s. 123. 
Chrystusa z Kościołem i że przez dobrą intencję przyjęli zamysł Boży odnoszący się do małżeństwa, a zatem, przynajmniej implicite, chcą tego, czego chce Kościól, kiedy sprawuje obrzęd sakramentalny małżeństwa. A więc sam fakt, że w ich prośbie są obecne także względy o charakterze społecznym, nie może usprawiedliwiać ewentualnej odmowy ze strony duszpasterzy".

3. Wobec pojawiających się postulatów, ażeby dopuszczając do ślubu w Kościele, „brać pod uwagę stopień wiary nowożeńców”, Jan Paweł II dystansuje się z trzech powodów: mianowicie wiąże się to z „ryzykiem bezpodstawnych i dyskryminujących osądów”. Ponadto, „z ryzykiem wywołania wątpliwości co do ważności małżeństw już zawartych, z wielką szkodą dla wspólnot chrześcijańskich, oraz nowego, bezpodstawnego niepokojenia sumień małżonków". Do tego dochodzi powód ekumeniczny. Mianowicie, gdyby stanąć na stanowisku, że do ważnego zawarcia sakramentalnego małżeństwa potrzebna jest wiara, zaowocowałoby to „niebezpieczeństwem kwestionowania czy też poddania w wątpliwość ważności sakramentalnej wielu małżeństw braci odłączonych od pełnej komunii z Kościołem katolickim, stając w ten sposób w sprzeczności z tradycją kościelną".

4. Zarazem wiara jest dla małżeństwa sakramentalnego czymś aż tak fundamentalnie ważnym, że w przypadku, kiedy mimo wysiłków duszpasterza nowożeńcy mają dla niej zero zrozumienia, nie należy ich do ślubu kościelnego dopuszczać. Tak ważną wypowiedź trzeba zacytować: „W przypadku, kiedy pomimo wszystkich poczynionych kroków nowożeńcy wyraźnie i formalnie dają do zrozumienia, że odrzucają to, co Kościół chce dopełnić sprawując obrzęd małżeństwa ochrzczonych, duszpasterz nie może dopuścić ich do obrzędu. Nawet jeśli czyni to z żalem, musi przyjąć do wiadomości tę sytuację i uświadomić zainteresowanych, że w tym stanie rzeczy nie Kościół, ale oni sami stanowią przeszkodę do odbycia obrzędu, o który proszą”. Znamienne, 
że nawet w takiej sytuacji Jan Paweł II nie wspomina, jakoby miało się to wiązać z ryzykiem zawarcia nieważnego małżeństwa.

Ten fragment adhortacji Familiaris consortio jest poniekąd odpowiedzią kościelnego Magisterium na ostrożny, ale jednoznaczny głos Międzynarodowej Komisji Teologicznej z roku 1977, podpowiadający możliwość zastanawiania się nad ewentualnością nieważności małżeństwa ze względu na brak wiary nupturientów. Przypomnijmy tamtą wypowiedź: „Także sakrament małżeństwa, podobnie jak inne sakramenty, udziela łaski na mocy dzieła dokonanego przez Jezusa Chrystusa, a nie tylko wiary przyjmujących sakrament. Nie oznacza to jednak, że w sakramencie małżeństwa łaska zostaje udzielona niezależnie od wiary lub w ogóle bez wiary. Wynika z tego, zgodnie z klasycznymi zasadami, że zakłada się wiarę z racji «przyczyny dysponującej» do owocnego skutku sakramentu. Z drugiej strony, ważność sakramentu nie zakłada w sposób konieczny, aby był on owocny. [...] Osobista wiara zawierających małżeństwo nie konstytuuje, jak to zostało podkreślone, sakramentalności małżeństwa, ale brak osobistej wiary wystawia na ryzyko ważność sakramentu”'s.

Otóż wydaje się, że ostatnie zdanie tej wypowiedzi należałoby sprostować. To nie jest tak, że brak osobistej wiary u ochrzczonych nupturientów wystawia na ryzyko ważność sakramentu. Jest raczej tak, że brak w nich osobistej wiary wystawia na ryzyko godziwość ich przystąpienia do ślubu kościelnego.

Na zakończenie powiem jeszcze, że zależało mi na tym, ażeby niniejsza wypowiedź była krótka, toteż nie podjąłem analizy niezwykle ważnych dla naszego tematu wypowiedzi Jana Pawła II, jakie znalazły się w przemówieniach do członków Trybunału Roty Rzymskiej z 1 lutego 2001 roku oraz z 30 stycznia 2003 roku.

13 Od wiary do teologii. Dokumenty Międzynarodowej Komisji Teologicznej 1969-1996, red. J. Królikowski, Kraków 1999, s. 95. 


\section{SUMMARY}

\section{Is faith needed to contract a valid marriage?}

The paper is a modest try to provide a short and easy to understand answer to the question contained in the title. First, the author makes a distinction between faith understood as the matter of faith and as the act of faith, that is, a personal attitude to God. The distinction in question is illustrated by the citations taken from the enunciations of the Magisterium of the Church. The conclusion of the paper is that the theology today is still unable to give a clear-cut answer to the very important question. As a consequence, canon law, which by its nature is based on the theological findings, still cannot help solving pastoral and legal complications that come from the unsolved problem.

Keywords: faith, marriage, contracting marriage, valid marriage

Jacek Salij, Czy do ważnego zawarcia sakramentalnego matżeństwa potrzebna jest wiara?, [w:] Znaczenie wiary dla matżeństwa: w kierunku zmiany prawa, red. Piotr Kroczek, Kraków 2016, s. 107-118 (Annales Canonici Monographiae, 4).

DOI: http://dx.doi.org/10.15633/9788374385220.07 